\title{
尿管膀胱新吻合術における尿管縫縮
}

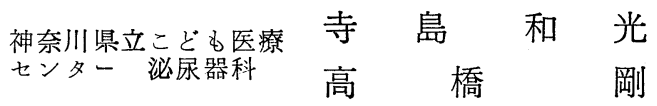

\section{URETERAL TAPERING}

\author{
Kazumitsu Terashima and Go Takahashi \\ Department of Urology, Kanagawa Children's Medical Center, Yokohama
}

Our experience with ureteral tapering at the time of ureteroneocystostomy in 9 megaureters is presented. 7 ureters were improved while 2 were failures with postoperative reflux. Ureters more than $1 \mathrm{~cm}$ in diameter usually require tapering in children. Our surgical technique for ureteral tapering is as follows:

1. Lower one third to half of the ureter is dissected and kinks straightened and excess length excised.

2. A longitudinal strip of ureteral wall (5-8 cm long) is excised and its size is reduced to $4-8 \mathrm{~mm}$ in diameter.

3. Ureteral edge is reapproximated with a running 4-0 chromic catgut stitch.

4. The ureter is reimplanted into the bladder through a long $(3-5 \mathrm{~cm})$ submucosal tunnel.

5. A $5 \mathrm{Fr}$. or $8 \mathrm{Fr}$. splint catheter is placed in the ureter for 10 to 14 days postoperatively.

6. Tapering is usually limited to the lower ureter and upper ureteral repair is rarely indicated.

\section{緒 言}

膀脂尿管逆流（以下 VUR と略）や尿管下端狭窄にた いして尿管膀胱新吻合術を拁こなう場合に考慮すべき 条件がいくつかあるが，尿管の太さも大切な条件の一つ であろう，すなわち，あまり太い尿管をそのまま膀胱に らえこんだのでは手術が失敗するおそれがある。そのた め，尿管を縫縮したり cuff を作つたりする方法がとら れている。

われわれはこれまで著明な拡張のみられた 9 尿管（9 症例）にたいして尿管縫縮 (ureteral tapering または tailoring）を併用した尿管膀胖新吻合術をおこなつたの で，その手術々式と成績を述べ，本法に関する文献的考 察も括こなら。

\section{症例}

9 症例は男子 8 例, 女子 1 例で, 手術時の年龄は 1 歳 1 カ月から 5 歳11カ月までであり， 8 例はVUR 症例 で，1 例は尿管下端狭窄症例である。VUR 症例では逆 流は 5 例が両側に，3 例が片側にみられ，両側例では尿 管膀胱新吻合術は両側同時におこなつた。しかし，縫縮 を括こなつたのは各症例に 1 尿管ずつであつた，尿管の 太さは部位によつて異なつていたが，新吻合すべき尿管 下端面の直径について手術中に測定すると13mm から $29 \mathrm{~mm}$ (平均 $18 \mathrm{~mm}$ ) までであり, 縫縮後の直径は $4 \mathrm{~mm}$ から $9 \mathrm{~mm}$ までであつた（表 1 ）。手術後の観察期間は 1 年から 3 年 (平均 1 年 9 カ月) までである.

\section{表 1 症例}

\begin{tabular}{|c|c|c|c|c|c|c|}
\hline \multirow{2}{*}{ 症例 } & \multirow{2}{*}{ 性 } & \multirow{2}{*}{ 年 齢 } & \multirow{2}{*}{ 診 断 } & \multicolumn{2}{|c|}{ 尿管下端直径 } & \multirow{2}{*}{ 成績 } \\
\hline & & & & 縫縮前 & 繾縮後 & \\
\hline S. & 男 & 2 歳 6 力月 & 両側 VUR & $14 \mathrm{~mm}$ & $9 \mathrm{~mm}$ & 不良 \\
\hline N. & 男 & 1 歳11力月 & 両側 VUR & $1 \mathrm{~mm}$ & $9 \mathrm{~mm}$ & 不良 \\
\hline Y.T. & 男 & 1 歳 1 力月 & 両側 VUR & $14 \mathrm{~mm}$ & $5 \mathrm{~mm}$ & 良好 \\
\hline T. K. & 男 & 4 歳 5 力月 & 両側 VUR & $13 \mathrm{~mm}$ & $4 \mathrm{~mm}$ & 良好 \\
\hline N. N. & 男 & 3 歳 4 力月 & 左側 VUR & $29 \mathrm{~mm}$ & $8 \mathrm{~mm}$ & 良好 \\
\hline K. M. & 女 & 4 歳 4 力月 & 右側 VUR & $16 \mathrm{~mm}$ & $5 \mathrm{~mm}$ & 良好 \\
\hline Y.S. & 男 & 4 歳 9 力月 & 両側 VUR & $16 \mathrm{~mm}$ & $5 \mathrm{~mm}$ & 良好 \\
\hline S. O. & 男 & 3 歳 0 力月 & 左側 VUR & $21 \mathrm{~mm}$ & $5 \mathrm{~mm}$ & 良好 \\
\hline K. A. & 男 & 5 歳11力月 & 尿管下端狭窄 & $19 \mathrm{~mm}$ & $4 \mathrm{~mm}$ & 良好 \\
\hline
\end{tabular}

手術々式

膀脱へは Pfannenstiel's incision で到達する．膀胱は 縱に切開するまず尿管を豩離するが，この 際尿管口 
も含めて膀腃から完全に切り離すようにする．そのため には尿管内にスプリントカテーテルを挿入しながら打こ ならと壁内尿管の剥離がしやすい，尿管剝離の範囲は尿 管の太さ, 蛇行屈曲の程度, 壁の血管の発育状態などで 決める．尿管があまり太くなく蛇行も軽い場合は一般に 血管の発達もあまりよくないので, 㕷離は必要最少限に とどめ, 周囲から入つてくる栄養血管はなるべく切断し ないように細心の注意を払う．その場合でも腸骨動脈と の交差部附近までの剝離なら問題はないと考えられる. 尿管がかなり太くかつ蛇行している場合はもつと上まで 剝離する必要があるが，このような尿管は幸い血管の発 達もよいので広範な剥離による血行障害の扣それは少な い. しかし蛇行がかなり強くても上部1/3を剥離する必 要はほとんどない，下部尿管さ光完全に治しておけば上 部尿管は時期がたつにつれて細くなると同時に蛇行も改 善してくることが多いからである。

尿管が剝離され蛇行がまつすぐにされると，そのまま 新吻合を抗こならには長すぎることが多いので下端を一 部切除することが多い.われわれの症例でも全例におい て余分な尿管下端を $2 \sim 4 \mathrm{~cm}$ 切除してから新吻合術を 扣こなつている.

尿管縫縮の長さは，最終的に尿管が膀脱にう壳こまれ た状態で縫縮の上端が膀胱壁よりやや近位にくるように する．尿管が非常に太い場合は縫縮しない部位とした部 位を境として尿管の直径が極端に変わるので尿がスムー スに流れない扔それがある。そのような時は縫縮はやや 長目にし，尿管下部が全体として漏斗状を呈するように 形成する。

縫縮して最終的に尿管の太さをどれ位にするかは患者 の年齢, 尿管壁の性状, 粘膜下トンネルの長さなどを参 考にして決めるが，一般に下端面の直径が $4 \sim 8 \mathrm{~mm}$ に なるようにする，尿管壁の切除の仕方は，まず尿管を必 要な長さだけ縱に切り開き, 血管分布の状態から残すべ き部分を決め, 次いで余分な部分を切除する。切除端は 4ー0クロミック腸線で連続縫合を括こない, さらに 5 一0クロミック腸線でところどころ補強用の結節縫合を おこなう・ただし，下端約 $2 \mathrm{~cm}$ はすべて結節縫合とす る.

尿管膀胱新吻合術は粘膜下トンネル 法でおこない， cuff は作らない，新らしい尿管口は古いのよりもさら に膀脱頝部に近い位置にくるようにする。トンネルの長 さは尿管直径の 5 倍かそれ以上になるように作るので 3 $\sim 5 \mathrm{~cm}$ 位である. 手術後尿管内にスプリントカテーテ
ルとして 5 または 8 フレンチサイズの柔かいポリェチレ ソチューブ（栄養チューブ）を10１4日間留置する．膀 脱内には男子では膀胱㿉としてマレコットカテーテル を, 女子では尿道よりバルンカテーテルを $2 \sim 3$ 週間留 置する．上部尿路が著しく拡張している場合は decom pression の意味で尿管内スプリントカテーテルの留置期 間を長目にする。

\section{手術成繶}

9 症例の 5 万 症例は成績が良好で, 術後の逆流再 発, 尿管狭窄, 尿漏などの合併症はない，術前にみられ た水腎症や水尿管症は著明改善し, 尿路感染も消失し ている. 残りの 2 症例 (VUR 症例) は術後 3 力月以内 に逆流が再発した（表 1).な拉，この 2 例については， 1 例は再手術をおこない治癒せしめたが，も51例は逆 流の程度が術前と比べて軽度で腎機能障害も進行してい ないので経過を観察している。

\section{考按}

1. 尿管縫縮の適応について

尿管膀脂新物合術を执こなら際, 尿管が著しく桩張し ていれば尿管をあらかじめ縫縮する必要がある。すなわ ち，尿管壁の一部を短冊形に切除することによつてその 太さを適当なサイズに縮め, 尿の運搬をよりスムースに し，かつ尿が流れない時には尿管内腔が完全に閉塞する ようにする.このようにして尿管機能の改善をはかるの が綎縮の目的といえる ${ }^{1)}$. 拡張した尿管は同時に蛇行屈 曲していることが多いので, 縫縮の際は尿管をまつすぐ にし，長さが余分ならば下端を切除する，一般に尿管縫 縮といえばこのような一連の操作がおこなわれるとみな してよい.

本法については古くは1954年に Nesbit らが臨床例を 報告しているが，手術成績は悪く ${ }^{2)}$ ，その後あまりあま りおこなわれなかつたようである。しかし，尿管膀胱 新吻合術として画期的な方法である Politano-Leadbetter 法 $(1958)^{3)}$ と Paquin 法 $(1959)^{4)}$ が登場してからは本法 がしだいに怙こなわれるよらになり，それに伴つて手術 成績も向上してきている。

Johnston はいわゆる primary mega-ureter 33尿管縫 縮を併用した尿管膀胱新吻合術を执こない，比較的よ い成績をおさめている゙)。しかし，いわゆる refluxing mega-ureter 29尿管にたいしておこなつた手術成績はか んばしくない閸題となるのは，いずれの論文 においても “mega-ureter” の定義が記載されていない ため, どの程度の太さの尿管に縫縮をおこなつたかが不 
明だといらことである。

Bischoff $^{7)}{ }^{8)}$, Hendren ${ }^{910) 11)}$, McLaughlin $5^{12)}$, Hodgson ら ${ }^{13)} ら$ も本法を抗こなつた多くの症例を報告してい るにもかかわらず，その適応についてはやはり明確に は述べていない。しかし，これら論文の文面や插入され たレントゲン写真の所見から察する限り，あまり太くな い尿管にたいしても縫縮を扣こなつているようである。

いつぽう，Williams らは尿管の内径が $1 \mathrm{~cm}$ をこ光 たら縫縮するとのべ ${ }^{14)}$ ，Tanagho も直径 $1 \mathrm{~cm}$ 以上なら ば扣こない(15)16)，Pitts らも $1 \mathrm{~cm}$ を縫縮の下限として いる ${ }^{17)}$ ・このように本法の適応を明示している論文では 尿管直径が $1 \mathrm{~cm}$ 以上とするものが多いようである.

それでは $1 \mathrm{~cm}$ 以上の尿管はすべて縫縮が必要かとい ら, Tanagho は尿管筋層の発育がよく, 蠕動が盛んで 収縮時に内腔が完全に閉塞するならば必ずしも必要では ない，と述べている ${ }^{15)}$ 。われわれはこれまで約70尿管の 尿管膀胱新吻合術をおこなつたが，その経験からすると 小児においてはやはり尿管直径が $1 \mathrm{~cm}$ 以上ならば縫縮 が必要であると考えている，しかし，直径 $1 \mathrm{~cm}$ 以下の 尿管でも蠕動の弱いものや患児の年齢が小さい場合は縫 縮 した注うがよかつたのではないかというような症例 や，逆に $1 \mathrm{~cm}$ 以上の尿管でも縫縮せずによい成績をお さめている症例があり， $1 \mathrm{~cm}$ という数值は一応の目安 と考えるべきであろう．結局，縫縮の適応 は患者の年 齢, 術前の透視撮影による尿管蠕動の状態, 術中の尿管 の性状（太さ, 筋層の厚さ, 血管の分布, 蠕動) などか ら総合的に判断して決めるしか方法はないと思われる。

\section{2. 手術々式について}

尿管全体が拡張していてもまず下部尿管を縫縮する， といらことについては多くの著者の意見はほぼ一致して いる。しかし縫縮の長さについては様々である。Johnston は尿管下部 $3 \mathrm{~cm}$ を $^{5)}$ 。 Paquin は $5 \mathrm{~cm}$ 以下を ${ }^{18)}$, Williams らは10〜12cm を ${ }^{14)}$ ，Tanagho は下 $1 / 2 \sim 2 / 3$ を(15)，または5〜7.5cm を(19)，McLaughlin ら Hendren $^{109}$ は腸骨動脈との交差部まで縫縮すると述べて いる．この場合も尿管の性状によつて決めるのが一番良 い方法と思われるが，われわれは新吻合がおこなわれた 状態で縫縮の上端が膀胱壁よりやや近位（腎側）にくる ようにし，非常に太い尿管ならばもつと長く縫縮するよ らにしている。

縫縮の方法は，尿管内に10１4フレン゙チサイズのカテ ーテルを挿入しそのサイズに合らように余分な尿管壁を 短冊形に切除縫合するのが一般的である ${ }^{10) 17) 19) 。 H o d g s-~}$ on らは逆にあらかじめ綘合系をかけておき，そのあと で余分な尿管壁を切除する方法をとつている ${ }^{13)}$.わ狄 れの場合はまず尿管壁を縌に切り開き，血管分布などを 参考にして残すべき部分を決め, 次いで余分な部分を切 除しているが，このほうがより合理的で安全であると考 えている. 切除端の縫合の仕方は結節縫合 ${ }^{719)}$ または連 続縫合 ${ }^{1012) 13)}$ であるが，両者に優劣の差はほとんどない ようである。縫縮して最終的に尿管の太さをどれて位にす るかについて明確に記載した文献は非常に少ないが，そ れは症例毎にいろいろの条件を参考にして決める必要が あるので一般論としていえないためであろう。われわれ の場合もかなり幅をもたせてあるが，尿管下端面の直径 が 4 〜 $8 \mathrm{~mm}$ になるように縫縮している。

尿管膀胱新吻合術はいわゆる粘膜下トンネル法が一般 的である。トンネルの長さについては Hendren は 3 $4 \mathrm{~cm}^{15)}$ ，Paquin は尿管直径：トンネル長=1：5にな るようにする18), と述べているが, Paquin の方法のほ らがより合理的であろら。手術後しばらくたつてから膀 胱鏡で調べると，トンネルの長さが手術時よりもかなり 短かくなつていることが多い。トンネルが長すぎて困る ことはまずないので，われわれはなるべく長目に作るよ らにしている。

下部尿管の縫縮後に上部尿管に拡張 が残つている場 合, Hendren は積極的にその部分の形成術をおこなつ ている(10)が，Tanagho はそのような必要はまずない， としている ${ }^{19)}$. われわれの症例で上部尿管の形成術をお こなつたものはない，それは，図1のように縫縮しなか つた部分の拡張はたしかにみられるが，それをわざわざ 細く形成するほどのことはない症例ばかりだつたからで ある.もし上部尿路全体がはじめから著しく拡張してい て尿管直径が $3 \mathrm{~cm}$ 以上もあるような症例なら Hendren のように下も上も手術すべかもしれない：しかし，そ のような場合はむしろあらかじめ腎瘦術や loop cutaneous ureterostomy を設置し, 上部尿路の decompression をはかつてからあらためて治療方針をたてるべきと考光 る.

3. 手術成績について

9 例のうち2 例は手術が失敗しているが，これらは尿 管縫縮を手がけたばかりの頃の症例であるためテクニッ クが不慣れだつたのが原因と思われるが，直接には縫縮 が不十分だつたためと考えている. その後おこなつた 7 例はすべて成功を执さめている。

文献的にみると, Hendren ${ }^{10)}$ や Hodgson $ら^{13)}$ の手術 
図 $1 \mathrm{~A}$ 症例 N.N. の嘀睄撮影

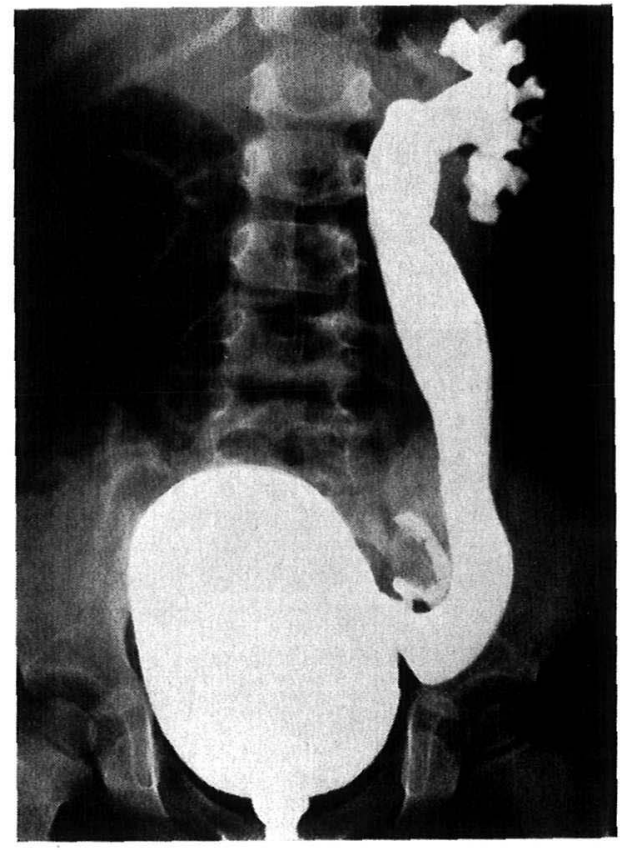

図 $1 \mathrm{~B}$ 同一症例の術前 IVP

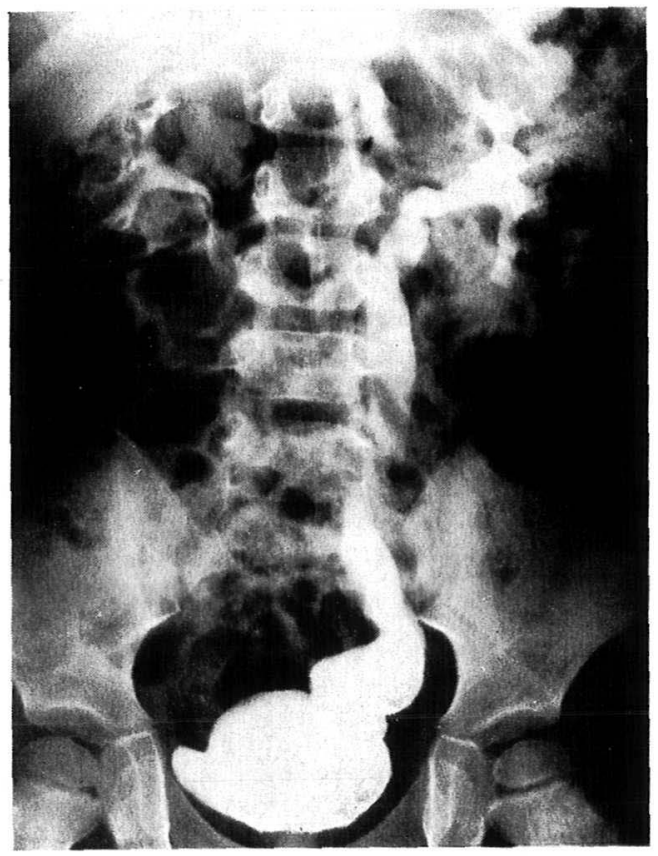

図1 C 同一症例の術後 6 力月目の IVP

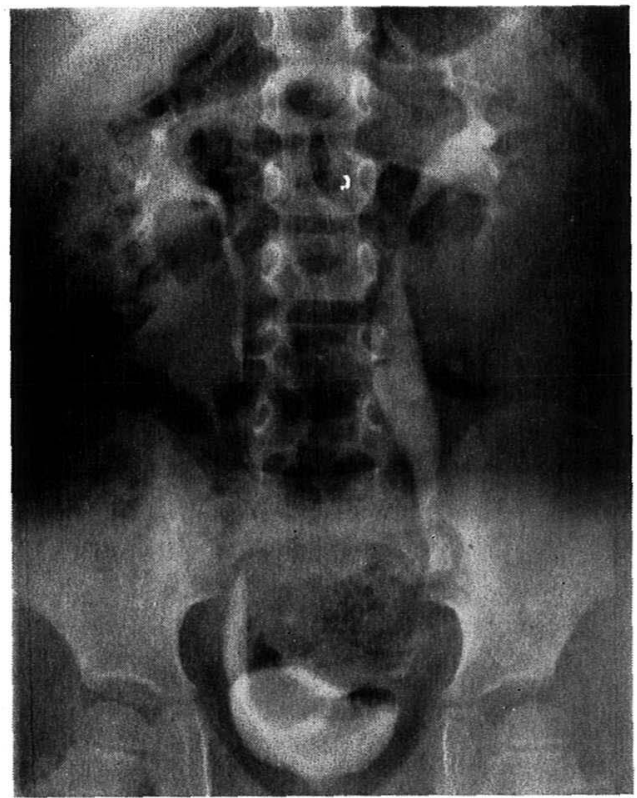

成績は良いが， Belman $5^{1)}$, Johnston $5^{6)}$, Derrick ${ }^{20)}$ らの成績はかなり悪く，この手術が決して簡単ではない ことを示している.

以上，尿管縫縮についてわれわれの手術術式と成績を 述べ, 諸家の報告と比較検討してみた。本法の適応とな るような症例がもともと少ないため，人によつて治療方 針が異なるのもやむを得ないと思われる，さらに，尿管 桩㲀の程度が一見して同じようであつても患者の年龄や 原因疾患（逆流や狭窄など）によつて尿管の性状がかな り違らことがあり, 縫縮の方法を画一的に決められない といら難しさがある. 今後はさらに臨床経験をつみ, 動 物的実験などによる基礎的な研究を和こならことによつ てもつとも客観性に富んだ治療方針をたてることが課題 であろう。

\section{結語}

1）疗管縫縮を併用した尿管膀胱新吻合術を 9 症例, 9 尿管におこなつた。 その結果, 7 例は術後成績は良好 であるが，2 例は逆流が再発した。

2）われわれの抗こなている手術々式は次の通りで ある。

A ．小児の場合，一般に尿管直径が $10 \mathrm{~mm}$ をこえたら 尿管縫縮を就こなう。

B，尿管は縫縮して最終的に $4 \sim 8 \mathrm{~mm}$ の直径にす る。 


\section{C ・縫縮する長さは，その上端が膀胱壁よりやや近位} にくるようにする。

D . 尿管壁の切除はなるべく血管の少ない面を選ぶ.

E . 尿管膀胱新吻合術はいわゆる粘膜下トンネル法で 扣こない，トンネルの長さは $3 \sim 5 \mathrm{~cm}$ とする.

F . 尿管内のスプリントカテーテルは10～14日間留置 する。

G . 上部尿路が著しく拡張している場合は一時的な尿 路変更をすべきである.

(本論文の要旨は第41回日本泌尿器科学会東部連合地 方会（1976年）において発表した。）

\section{文献}

1) Belman, A.B.: Urol. Clin. North Am., 1, 497, 1974.

2) Nesbit, R.M. and Withcombe, J.F.: J. Urol., 72, 162, 1954.

3) Politano, V.A. and Leadbetter, W.F.: J. Urol., 79, 932, 1958.

4) Paquin, A.J.: J. Urol., 82, 573, 1959.

5) Johnston, J.H.: in Paediatric Urology, Williams, D.I., p. 164, Appleton-Century-Crofts, New York, 1968.

6) Johnston, J.H. and Farkas, A.: Brit. J. Urol.,
47, 153, 1975.

7) Bischoff, P.: Brit. J. Urol., 29, 416, 1957.

8) Bischoff, P.F.: J. Urol., 107, 133, 1972.

9) Hendren, W.H.: J. Urol., 101, 491, 1969.

10) Hendren, W.H.: in Problems in Paediatric Urology, Johnston, J.H. and Scholtmeijer, R.J., p. 1, Excerpta Medica, Amsterdam, 1972.

11) Hendren, W.H.: J. Urol., 113, 238, 1975.

12) McLaughlin, A.P., Leadbetter, W.F. and Pfister, R.C.: J. Urol., 106, 186, 1971.

13) Hodgson, N.B. and Thompson, L.W.: J. Urol., 113, 118, 1975.

14) Williams, D.I. and Hulme-Moir, I.: Brit. J. Urol., 42, 140, 1970.

15) Tanagho, E.A.: Brit. J. Urol., 42, 410, 1970.

16) Tanagho, E.A.: J. Urol., 106, 194, 1971.

17) Pitts, W.R. and Muecke, E.C.: J. Urol., 111, 468, 1974.

18) Paquin, A.J.: in Urologic Surgery, Glenn, J.F. and Boyce, W.H., p. 232, Harper \& Row, New York, 1969.

19) Tanagho, E.A.: in Reviews in Paediatric Urology, Johnston, J.H. and Goodwin, W.E., p. 85, Excerpta Medica, Amsterdam, 1974.

20) Derrick, F.C.: J. Urol., 108, 153, 1972. （1976年11月 1 日受付） 